\title{
Scientific Appraisal of Classical Calcination Process of Kushta (Calx) in Reference to Calx of Copper Sulphate
}

\author{
Sumera Mehfooz , Abdul Wadud ${ }^{1, *}$, Hamiduddin ${ }^{2}$, Rajeev Ranjan ${ }^{3}$ \\ 'Department of IImul Advia (Pharmacology), National Institute of Unani Medicine (NIUM), Bengaluru, Karnataka, INDIA. \\ 2Department of Ilmul Saidla (Pharmacy) National Institute of Unani Medicine (NIUM), Kottigepalya, Magadi Main Road, Bengaluru, Karnataka, INDIA. \\ ${ }^{3}$ Department of Materials Engineering, Indian Institute of Science, Bengaluru, Karnataka, INDIA.
}

\begin{abstract}
Background: Kushta, a dosage form of Unani medicine is prepared by employing well-designed procedures. The correct procedure ensures the production of Kamil (perfect) Kushta considered as safe, while a deviation from the method results in an Naqis (imperfect) Kushta, which is liable to induce adverse effects. The characteristic parameters of such Kushta are not discrete enough to distinguish perfect and imperfect Kushta (s). Purpose of the study was analysis of Kushta taking Kushta Tutia (Copper sulphate) (KT) as example for characterization of the perfect and imperfect manufacturing process and to establish standard parameters. Methods: For the preparation of Kushta Tutia Kamil (KTK) the method mentioned in classical Unani text Kitabut Taklees was employed whereas for preparation of Kushta Tutia Naqis (KTN), deviations were made in standard method. Analytical techniques viz. XRD, FESEM and ICP-MS were used for characterization of KTK and KTN along with some physicochemical parameters. Acute toxicity study was also carried out by OECD Guidelines (423). Results: Findings indicated differences between KTK and KTN in terms
\end{abstract}

of particle size, trace elements and end-product. Copper sulphate $\left(\mathrm{CuSO}_{4}\right)$ phase changed into Calcium sulphate and altered Copper phase - $\mathrm{CU}$ in KTN and Anhydrite Calcium Sulphate - $\mathrm{Ca}\left(\mathrm{SO}_{4}\right)$ and CUO in KTK. No mortality was noted in KTK and KTN both up to $2000 \mathrm{mg} / \mathrm{kg}$. Conclusion: Differences in the analytical findings of KTN and KTK validated the perfect procedure of making KT, with end product displaying absence of toxic $\mathrm{CuSO}_{4}$ phase. Key words: Analysis, Kushta, Copper sulphate, Toxicity, Unani medicine.

\section{Correspondence}

\section{Prof. Abdul Wadud,}

Director NIUM (National Institute of Unani Medicine) and Professor, Department of Ilmul Advia (Pharmacology), Kottigepalya, Magadi Main Road,

Bangalore-560091, Karnataka, INDIA.

Email id: drwadud87@gmail.com

DOI: 10.5530/ijpi.2021.4.66

\section{INTRODUCTION}

Copper sulphate $\left(\mathrm{CuSo}_{4}\right)$ is a mineral origin drug found as blue crystalline masse ${ }^{1}$ in Unani medicine indicated internally in calx form, in Wounds, Infantile pneumonia, Pyorrhea, Syphilis, Leprosy, Boil, and Diarrhea etc, prepared after processing termed as 'Tadbeer' (detoxification). ${ }^{2-4}$ Its oral use is restricted; topically it is used in indolent ulcers, fistula, ringworm, conjunctivitis, ophthalmia, epistaxis, vaginitis, mouth ulcer, helminthiasis and leucorrhoea. ${ }^{1-5}$

In Unani Medicine, most mineral / metal origin drugs are used after processing or in a changed form such as calcined form to avoid adverse effect. Calcination is a process, which converts hard and harmful drugs into a usable, palatable and safe dosage form known as Kushta. It is the finest powder dosage from. ${ }^{6,7}$ The classical and also some conventional standardization criteria of this dosage form are not fully reliable and inapt for an elaborative distinction between perfect and imperfect end product. Unani physicians have discussed the characteristics of perfectly prepared calx based on subjective parameters like observation of color, odor, taste, and certain classical tests. Classical tests specific for Kushta / Bhasma are test for luster, fineness, ${ }^{8}$ floating test, ${ }^{9}$ curd and lemon test for colour changes, ${ }^{10}$ and wall stick test $\mathrm{t}^{11}$ etc. These parameters, nowadays, are thought obsolete because of lack of expert hands and are also not conclusive for fine assessment.

Few routine conventional methods for standardization of powder are also not fully reliable in case of Kushta. Specific methods have not yet been documented for standardization of Kushta. However, certain techniques, such as X-ray Diffraction (XRD), Field emission scanning electron microscope, energy dispersive spectroscopy (FESEM / EDS),
Inductively Coupled Plasma - Mass Spectrometry (ICP-MS) etc., can be used to develop methods of standardization of Kushta. XRD is a suitable technique for determination of crystal structure of the material and measurement of particle size in a polycrystalline aggregate. ${ }^{12,13}$ ICP-MS is a coupled technique useful in the determination of major, minor and trace elements. FESEM/ EDS can be used for topography, composition and particle size etc. of a substance. In this study analysis of on such Kushta preparation 'Kushta Tutia' (KT) a Kushta of Copper sulphate, with sophisticated instrument was done for its manufacturing process characterization of the perfect and imperfect Kushta and to develop its standardization data. Safety and efficacy is tested in in vivo studies for standardization and differentiation of two dosage forms.

\section{METHODS}

\section{Procurement of raw material, and chemicals}

Copper sulphate and the chemicals were procured from the local market of Bengaluru. Fresh margosa (Azadirachta indica A. Juss.) leaves were collected from the herbal garden of National Institute of Unani Medicine (NIUM), Bengaluru. Dung cakes were purchased from a nearby village. A voucher specimen of the test sample has been submitted to drug museum of NIUM with voucher specimen no.62/IA/Res/2019.

\section{Authentication of raw material}

Copper sulphate was identified by regional ore laboratory Bengaluru, Indian Bureau of Mines, vide K-23011/4/Chem/2018-19/Analys/ Bang/ 
OD. As Copper sulphate with $\mathrm{Cu}$ (Copper) percentage $24.06 \%$. Margosa leaf was authenticated at Institute of Trans-Disciplinary Health Science and Technology (FRLHT), Bengaluru as Azadirachta indica A. Juss. (Neem) Vide FRLHT Acc. No. 5059.

\section{Preparation of Kushta}

The Kushta was prepared by the method described in kitabut Taklees. ${ }^{6}$ KTK (Kushta Tutia kamil / Perfect calx of Copper sulphate) was prepared by taking $24 \mathrm{~g}$ of Copper sulphate, kept in a plate-like earthen pot below which fire was set by igniting cardboard. Over the drug, juice prepared of $1 \mathrm{~kg}$ Margosa / Neem leaves was poured drop by drop. The prepared material was converted into pellets of $6 \mathrm{~g}$ and dried in shade. The dried pellets were kept in an earthen pot covered with an earthen lid, sealed with clay and cloth called Gilehikmat. ${ }^{8}$ A pit was dug in which $960 \mathrm{~g}$ dung cakes were placed beneath and above the Gilehikmat, which was ignited for production of heat. The whole process was repeated 4 times on the same drug material with use of new juice of margosa leaves each time. After cooling, the final product was taken out for analysis. KTN (Kushta Tutia Naqis / Imperfect calx of Copper sulphate) was also prepared by the same method except for quantum of heat, dung cakes and quantity of Margosa / Neem leaves, which were halved. KTN was considered imperfect because of major deviation from the prescribed method of preparation.

\section{Characterization}

Conventional and micrometric methods: Conventional methods like ash values, moisture content $\mathrm{pH}^{14,10,15}$ Solubility and micrometric analysis like Bulk density, Tapped density, Hausner's ratio and Carr's index were employed for powder characterization ${ }^{16}$ for KTK and KTN.

Analytical methods: Analytical methods such as XRD (X-ray Diffraction), ICP-MS (Inductively Coupled Plasma - Mass Spectrometry), and FESEM / EDS (Field emission scanning electron microscope, energy dispersive spectroscopy) were applied ${ }^{9,13,14}$ for the entire four samples TP (Tutia powder / Copper sulphate powder), TB (Tutia Biryan / Roasted Copper sulphate), KTK (Kushta Tutia kamil / Perfect calx of CCopper sulphate) and KTN (KushtaTutia Naqis / Imperfect calx of CCopper sulphate).

\section{X-ray Diffraction (XRD) study}

Digital balance (Shimadzu Corporation, Japan AY 220), standard Sieve \# no. 200 (Test sieves IMPEX INDIA) was used to carry out XRD by using X-ray diffractometer with specifications as PAN analytical, $\mathrm{X}^{\prime}$ pert pro, X-ray source $\mathrm{CU} \mathrm{k} \alpha\left(\alpha=1.5418 \mathrm{~A}^{\circ}\right)$, operating voltage 40 $\mathrm{KV} / 30 \mathrm{MA}$, Phases were identified using automatic search program $\mathrm{X}$ 'Pert High Score Plus. The particle size (D) of the phase-in sample was calculated using the Scherer's formula $\mathrm{D}=0.9$ / cosis the wavelength of the x-ray used (1.5406 $\AA$ ), is full width at half maximum (FWHM) of the Bragg peak and the Bragg angle of the Bragg peak (Peak position). The basic relationship for determination of particle size using the XRD pattern is $0.9 / \beta \cos \theta$. The strong peak was chosen at different angles $(2 \theta)$. Powder method of diffraction was selected. Fine powder of samples $1 \mathrm{~g}$ was prepared for investigation. X-ray diffraction studies conducted on a different sample of KT were confirmed by comparing d-identified values with $\mathrm{d}$-standard peak values. The 2 -theta value and intensity of the peak (counts) were represented on $\mathrm{X}$ and Y-axis, respectively, higher peak (count) value indicates higher crystallinity of phase. ${ }^{11,12}$ XRD was carried out for powder of Copper sulphate $\left(\mathrm{CuSo}_{4}\right)$, Roasted powder of Copper sulphate, KTK and KTN, as sample 1, 2, 3 and 4.

\section{Field emission scanning electron microscope, energy} dispersive spectroscopy (FESEM / EDS)

FESEM / EDS can provide imaging techniques with resolutions in the range $1 \mathrm{pm}$ to $1 \mathrm{~nm}$. EDS is also used to provide elemental identification and quantitative compositional information. ${ }^{10,17-19}$ FESEM / EDS was done by equipment model, Carl Zeiss Ultra 55 field emission scanning electron microscope, energy dispersive spectroscopy was carried out for fine powder of Sample 1-TP, Sample 2 -TB, Sample 3 - KTN and Sample 4 -KTK.

1 pinch sample is coated with gold in sputter coater and trimmed to an appropriate size to fit in the specimen chamber and mounted on the holder, Electron beam is used to capture the morphology / topographical information from the specimen at EHT- $5 \mathrm{kV}$ with a working distance (WD) $9.8 \mathrm{~mm}$, signal A-SE2 and in different magnification. A small portion of the sample was sprinkled on to a double-sided carbon tape and mounted on gold stubs, to get electron image. The elemental analysis of sample 1 to 4 was also carried by using EDS for all the samples.

\section{Inductively Coupled Plasma - Mass Spectrometry (ICP-MS)}

ICP-MS analysis was done by Multi-wave Digestion method. Weighed $0.5 \mathrm{~g}$ of the sample in Multi-wave Digestion vessel added $7 \mathrm{ml}$ Nitric acid. HCL $1 \mathrm{ml}$, hydrogen peroxide and $1 \mathrm{ml}$ Milli Q water was taken. Vessel is closed and inserted in the Multi-wave digestion system. Microwave program runs the digestion program to completion and cools for the attending room temperature. Vessel was then open and sample transferred quantitatively to $25 \mathrm{ml}$ standard volumetric flask. Added $2.5 \mathrm{ml}$ of internal standard solution $(0.1 \mathrm{ppm})$ and made up to volume with Milli Q water. Blank was prepared without a sample in the same condition. Instrument parameters were set as described in the manufactures manual. The option of triplicate measurements was select for the detector and analysis mode was helium. The instrument tuned with a tuning solution to pass the fitness parameters. Manufacturer's recommended isotopes of the elements for measurements were selected. Sequence table starting with preparation blank, calibration standard series as per the number of samples and elements of interest was created. The sequence was then run. The element to be determined in $\mathrm{mg} / \mathrm{kg}$ was calculated automatically by the software by using the formula, $\mathrm{W}=[\mathrm{R} \mathrm{X} \mathrm{V} \mathrm{X} \mathrm{DF]} \mathrm{/} \mathrm{[M} \mathrm{X} \mathrm{1000];} \mathrm{where} \mathrm{W}$ is the mass fraction; $\mathrm{R}$ is the mass fraction of the element in the test solution, in ppb.; $\mathrm{V}$ is the volume of the digestion solution after being made up in ml.; DF is the dilution factor of the test solution.; $\mathrm{M}$ is the weight of the sample taken for the analysis in $\mathrm{gm} / \mathrm{kg} .{ }^{12}$

\section{Acute Toxicity Study}

Acute Toxicity Study was carried out according to OECD Guidelines (423) after approval of IAEC of NIUM. Ethical clearance certificate no. IAEC/2/15//IA. Thirty six healthy, young adult, nulliparous, nonpregnant female Wistar rats weighing 150-200 g, 8 -12 week old were procured from Biogen Laboratory Animal Facility (Registration No. 971/bc/06/CPCSEA Bangalore, India) and divided into two groups I and II containing 18 animals in each. Animals of group I were given KTK and group II was given KTN in different dosage. The above groups were further divided into three subgroups of 6 animals in each. In each subgroup, the three different doses was given in increasing quantity i.e. $50 \mathrm{mg} / \mathrm{kg}, 300 \mathrm{mg}$ and $2000 \mathrm{mg} / \mathrm{kg}$ body weight dissolved in $1 \mathrm{ml}$ distilled water. To know the acute toxicity the animals were observed individually for various toxic signs, like behaviour, changes in the skin, fur, eyes, respiratory, and circulatory signs, attention were directed for observations of tremors, convulsions, salivation, diarrhoea, lethargy, sleep and coma up to $24 \mathrm{hr}$. After 14 days, weights of the animal were 
recorded. Food intake, general behaviour, skin colour, skin pigmentation, body hair loss, palpable mass, motility, tremor and convulsions were observed for 14 days. ${ }^{20}$ At the end of experiment rats were euthanized by high dose of anesthesia Diethyl ether $5 \mathrm{ml}$ by placing individual animals into desiccators containing ether-saturated atmospheres.

\section{Statistical analysis}

The data were expressed as Mean \pm SEM and the values for the test groups were compared by using one-way analysis of variance (ANOVA) followed by Tukey- Kramer multiple comparisons test. The significance level was considered $(p<0.05)$.

\section{RESULTS}

For organoleptic properties, KTK was found as black, odorless, tasteless, smooth and lusterless whereas that of KTN was found blackish brown, peculiar in odor, metallic in taste, slightly course and shining. Moisture content was $1.52 \pm 0.03 \%$ and $0.74 \pm 0.06 \%$, total ash $1.20 \pm 0.00 \%$ and $1.54 \pm 0.10 \%$, acid insoluble ash $0.68 \pm 0.21 \%$ and $0.46 \pm 0.15 \%$, water soluble ash was $0.49 \pm 0.16 \%$ and $0.36 \pm 0.12 \%$ for KTN and KTK respectively. These values did not display significant difference. $\mathrm{pH}$ in $1 \%$ aqueous solution was $5.23 \pm 0.01$ and $6.23 \pm 0.01$; and $10 \%$ aqueous solution was $4.74 \pm 0.00$ and $5.22 \pm 0.00$, respectively for KTN and KTK. KTN was slightly soluble in ethanol and sparingly soluble in petroleum ether but insoluble in water. KTK was sparingly soluble in water, but freely soluble in organic solvents. Powder characterization tests of KTK and KTN displayed bulk density ( $\mathrm{gm} / \mathrm{ml}$ ) $0.56 \pm 0.01$ and $0.66 \pm 0.00$; Tapped Density (gm / ml) $0.85 \pm 0.01$ and $1 \pm 0.00$; Hauser's ratio1.50 \pm 01.5 and $1 \pm 0.01$; Carr's index; $34.18 \pm 1.56 \%$ and $34.05 \pm 0.71 \%$ respectively.

XRD of Sample TP displayed the presence of Chalcanthite; $\mathrm{Cu} \mathrm{\textrm {SO } _ { 4 }}$ $\left(\mathrm{H}_{2} \mathrm{O}\right)_{5}$ phase confirming the presence of Copper sulphate as the element [Figure 1]. Sample TB displayed phases of Copper Sulphate Hydrate - $\mathrm{Cu}$ $\mathrm{SO}_{4}$ ! $\mathrm{H}_{2} \mathrm{O}$, Copper Sulphate Oxide - $\mathrm{Cu} \mathrm{SO}_{4}$ and Bonattite - $\mathrm{Cu}+2 \mathrm{SO}_{4} ! 3$ $\mathrm{H}_{2} \mathrm{O}, \mathrm{XRD}$ pattern is depicted in [Figure 2]. [Table 1]

KTN displayed the presence of phase of Copper $(\mathrm{Cu})$, Calcium Sulphate $\left(\mathrm{CaSO}_{4}\right)$ and Bassanite $\left(\mathrm{CaSO}_{4} ! 0.5 \mathrm{H}_{2} \mathrm{O}\right)$. [Figure 3]. KTK displayed phase of Copper Oxide (CUO), Anhydrite Calcium Sulphate $\left(\mathrm{Ca}\left(\mathrm{SO}_{4}\right)\right.$, Potassium hydroxide $\left(\mathrm{KO}_{2}\right)$ [Figure 4] [Table 1]. Grain /Crystallite / particle size of phases of all the samples is depicted in Table 1.

XRD result concludes that Copper sulphate incinerated / calcined with margosa leaves converted in $\mathrm{CUO}$, and $\mathrm{CaSO}_{4}$ when perfect manufacturing procedure is followed. Particle size is gradually decreased from Copper sulphate in sample TP to TB and CU grain from KTN to

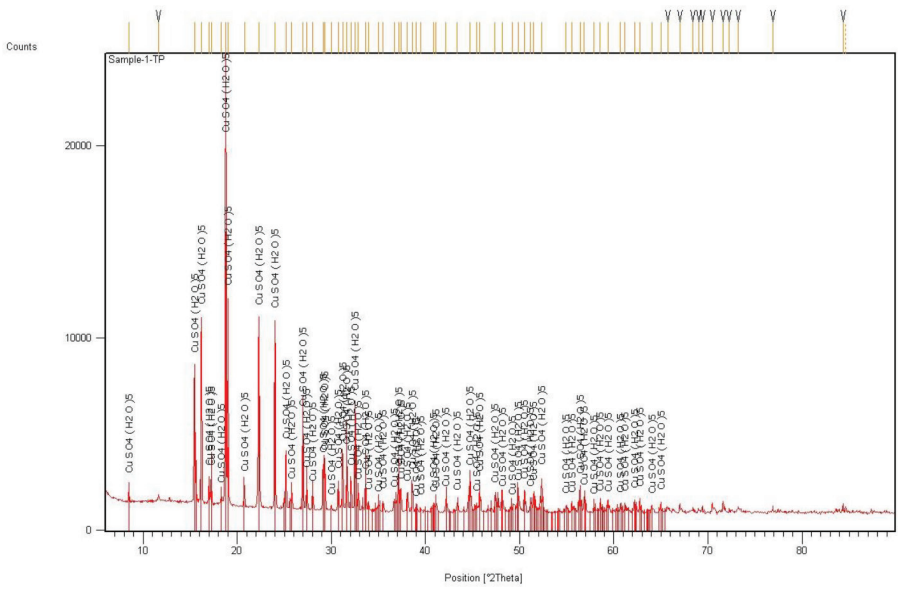

Figure 1: XRD, Sample -1-TP.

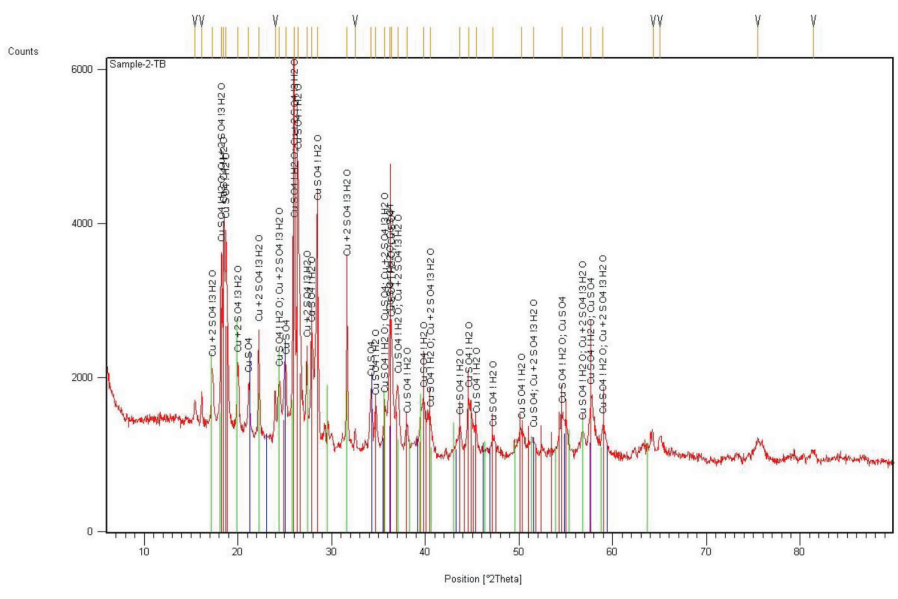

Figure 2: XRD, Sample -2-TB.

Table 1: Constituent phases detected and Crystallite / particle size by XRD of all the samples.

\begin{tabular}{|c|c|c|}
\hline Samples & Constituent phase & $\begin{array}{c}\text { Particle size in } \\
\mathrm{nm}\end{array}$ \\
\hline $\mathrm{TP}$ & Copper sulphate - $\mathrm{Cu} \mathrm{S} \mathrm{O} 4\left(\mathrm{H}_{2} \mathrm{O}\right) 5$ & 82.67 \\
\hline \multirow[t]{3}{*}{ TB } & Copper Sulphate Hydrate - $\mathrm{Cu} \mathrm{S} \mathrm{O}_{4} ! \mathrm{H}_{2} \mathrm{O}$ & 82.64 \\
\hline & Copper Sulphate Oxide - $\mathrm{Cu} \mathrm{S} \mathrm{O}_{4}$ & 41.92 \\
\hline & Bonattite - $\mathrm{Cu}+2 \mathrm{~S} \mathrm{O}_{4} ! 3 \mathrm{H}_{2} \mathrm{O}$ & 49.67 \\
\hline \multirow[t]{3}{*}{ KTN } & Copper - $\mathrm{Cu}$ & 37.61 \\
\hline & Calcium Sulphate - $\mathrm{CaSO}_{4}$ & 41.82 \\
\hline & Bassanite - $\mathrm{CaSO}_{4} ! 0.5 \mathrm{H}_{2} \mathrm{O}$ & 21.09 \\
\hline \multirow[t]{3}{*}{ KTK } & Copper Oxide - $\mathrm{CuO}$ & 33.58 \\
\hline & Anhydrite Calcium Sulphate - $\mathrm{Ca}\left(\mathrm{SO}_{4}\right)$ & 50.16 \\
\hline & Potassium hydroxide - $\mathrm{KO} 2$ & - \\
\hline
\end{tabular}

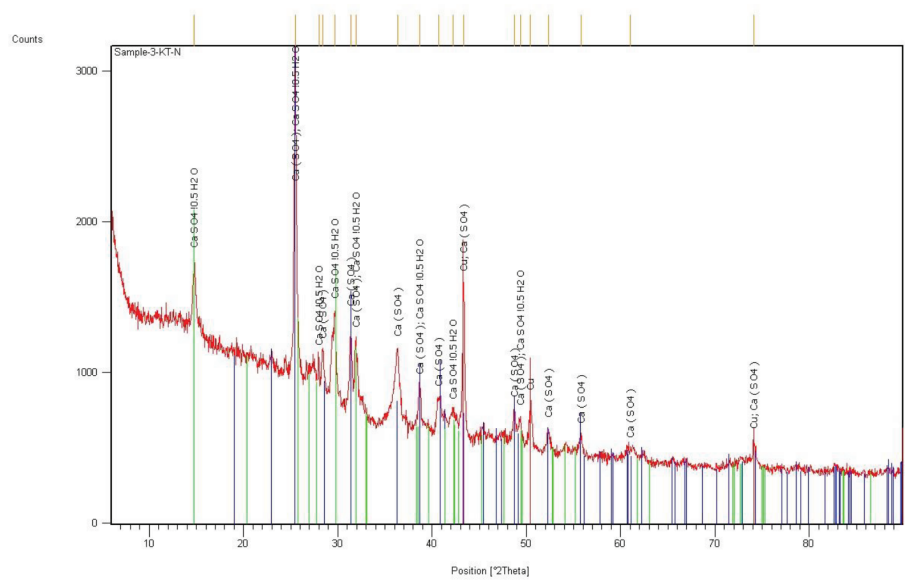

Figure 3: XRD, Sample -3- KTN.

KTK group, detail of all the element with particle size Copper sulphate and $\mathrm{Cu}$ phase all the samples is depicted in Table 1.

FESEM/EDS data was set in with FESEM particle size random assessment was done. Type of element with percentage was detected with EDX / EDS. suggested that KT in sample 1 to 4 belonged to the complex group 


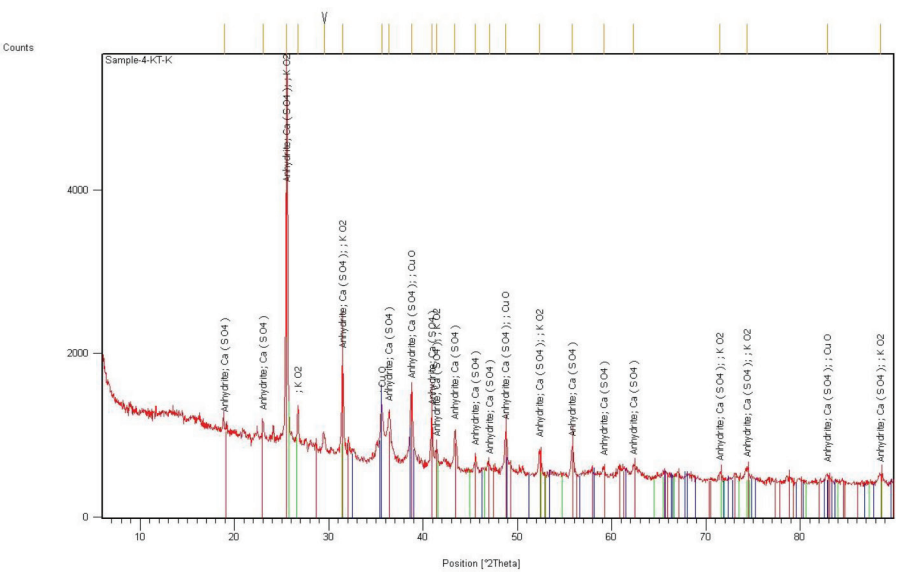

Figure 4: XRD, Sample-4- KTK.
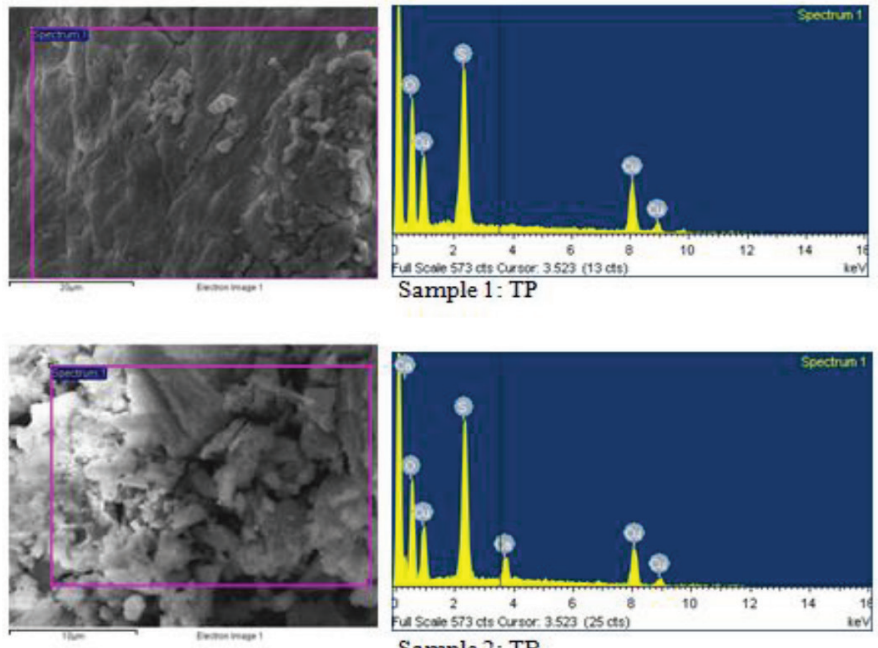

Sample 2: TB
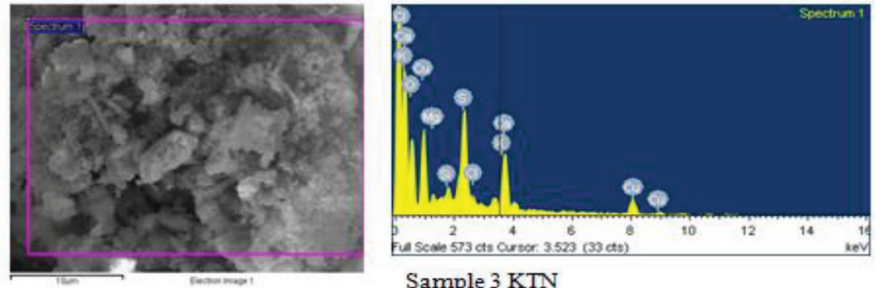

Sample $3 \mathrm{KTN}$
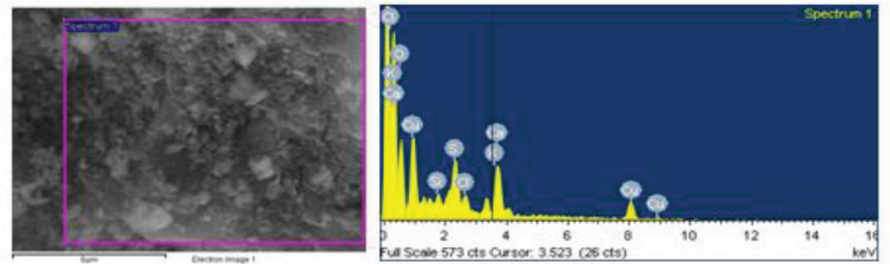

Sample 4 KTK

Figure 5: FESEM, EDS, TP and TB.

of minerals/elements containing in different proportions. [Figure 5, 6]. Particle size of (472 nm, $488 \mathrm{~nm}$ and $296 \mathrm{~nm}$.) for TP and $208 \mathrm{~nm}, 151$ $\mathrm{nm}, 107 \mathrm{~nm}$ ) for TB. Particle size of (170 nm, 132nm, $96 \mathrm{~nm}$, and $65 \mathrm{~nm}$ ) for KTN and ( $83.43 \mathrm{~nm}, 83.43 \mathrm{~nm}$ and $69.05 \mathrm{~nm}$ ) for KTK respectively was randomly observed. Morphology / topographical information of sample 1 to 4 was set in (Figure 7). Elemental analysis of sample carried out by EDS and its weight \% reveal presence of (O - 29.62, S-15.01 and $\mathrm{Cu}-55.37 \%)$ out of $100 \%$ in TP. (O -31.41, S-17.52, Cu - 46.95 and Ca $4.12 \%)$ in TB. Elemental analysis of sample by EDS and its weight \% reveal presence of $(\mathrm{O}-41.11, \mathrm{~S}-13, \mathrm{Cu}-24.47, \mathrm{Ca}-14.13, \mathrm{Mg}-1.65$, $\mathrm{Si}-2.13, \mathrm{Cl}-1.33$ and $\mathrm{K} 2.18 \%)$ in KTN. (O - 42.08, S - 6. 80, Cu - 29.33, $\mathrm{Ca}-12.73, \mathrm{Si}-2.07, \mathrm{Cl}-3.36$ and $\mathrm{K} 3.62 \%)$ out of $100 \%$ in KTK

ICP-MS: Trace elements / heavy metal and $\mathrm{Cu} \%$ in $\mathrm{KTN}$ were $\mathrm{Cu}(7.38$ $\%$ w/w), Ar (0.64 ppm), Cd (0.36 ppm), Hg (0.97 ppm), Pb (38.67 ppm), and in KTK were $\mathrm{Cu}(6.49 \% \mathrm{w} / \mathrm{w}), \mathrm{Ar}(0.56 \mathrm{ppm}), \mathrm{Cd}(0.29 \mathrm{ppm}), \mathrm{Hg}$ (0.06 ppm), $\mathrm{Pb}$ (27.02 ppm), respectively.

For Acute Toxicity study, all animals were carefully observed for development of any toxic signs at different time intervals 0, $30 \mathrm{~min}, 4$, $8,12,24 \mathrm{hr}$ and then daily for period of 14 days. No abnormal signs were observed in any of the animal group fed with KTK and KTN at the dose of 50, 300 and $2000 \mathrm{mg} / \mathrm{kg}$ b.w. No mortality was observed in any animal up to $24 \mathrm{hr}$. Body weight of KTK group on $0,8^{\text {th }}$, and $15^{\text {th }}$ was found to be
Figure 6: FESEM, EDS, KTN and KTK.
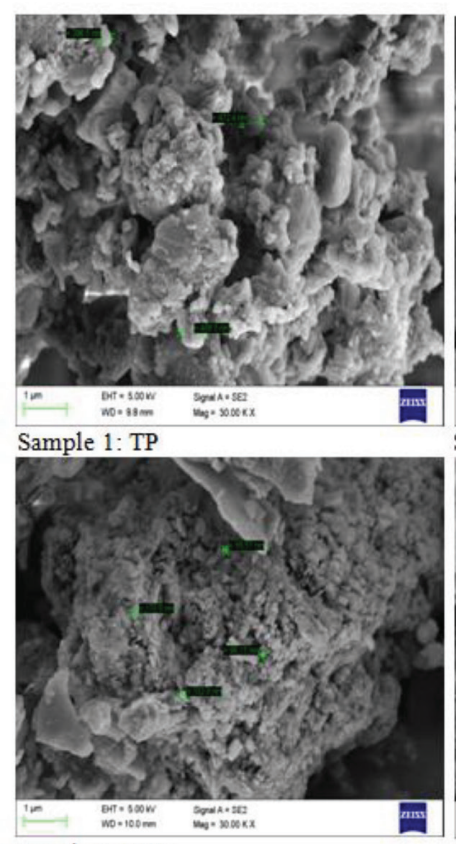

Sample 3: KTN

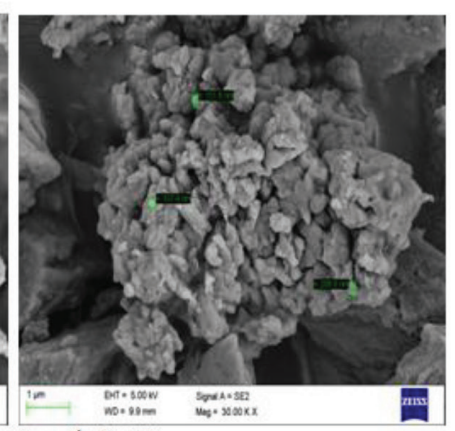

Sample 2: TB

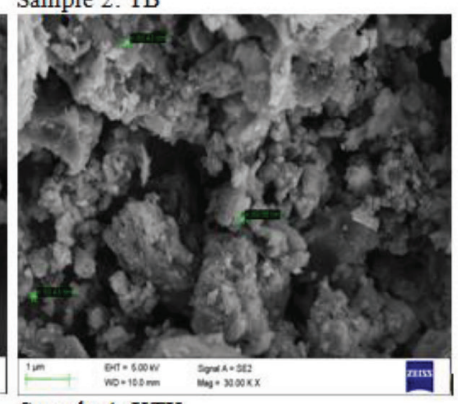

Sample 4: KTK
Figure 7: Topographic data FESEM of Sample 1- 4.

$163 \pm 6.24,163 \pm 5.68$ and $171 \pm 8.35$, body weight of animal treated with KTN was found to be $179 \pm 9.38,180 \pm 10.40$ and $194 \pm 10.97$, no reduction was observed in any group. No hair loss, No pigmentation on skin; No skin color changes was observed in any group, no palpable mass and keratosis was found in any group. No altered motility and convulsion / tremor occur in the animal of any group. Acute toxicity study did not show any toxicity sign in terms of general observation up to $2000 \mathrm{mg} / \mathrm{kg}$.

\section{DISCUSSION}

Organoleptic findings displayed some difference between KTN and KTK indicating that KTN is imperfectly formed. Findings revealed that deviation from the standard methods results in to imperfect endproduct. In conventional methods, ash value is considered an important parameter for detecting impurities of a drug. ${ }^{21}$ Incase of a Kushta, which has already been incinerated on a temperature higher than used for 
making ash, seems inapt, but it can establish its standards. ${ }^{11}$ Insignificant difference was observed in ash values of KTN and KTK. However, higher acid insoluble ash in KTN pointed out towards imperfectness. These findings are suggestive of the presence of elemental part in both samples. Some percentage of moisture was noted, may be due to the formation of Calcium sulphate. ${ }^{22}$ The moisture content in KTN was found more than KTK, due to less heat exposure in case of KTN. The changes in $\mathrm{pH}$ of a drug change the physical property. ${ }^{14} \mathrm{Kushta}(s)$ as oxides are usually basic. $\mathrm{pH}$ of KTK containing CUO was found to be higher than KTN which contained $\mathrm{Cu}$. It can be well explained that when Copper converts to Copper oxide ( $\mathrm{Cu} 2 \mathrm{O}$ ) becomes basic..$^{23}$ Increase of $\mathrm{pH}$ in KTK can also be explained with increased oxidation process, due to perfect incineration. Solubility can also act as an index of purity. ${ }^{11,14,15}$ Both samples were more soluble in inorganic solvents. The solubility of KTK was more than KTN which may be due to the small particle size of the former and less amount of $\mathrm{Ca}$ and $\mathrm{S}$ element found in $\mathrm{Ca}\left(\mathrm{SO}_{4}\right)$ phase, which is poorly soluble in water and was found more in KTN as evident in EDS and XRD analysis. ${ }^{24}$ [Table 1] Conventional micrometric methods like Bulk density, Tapped density, Hausner's ratio and Carr's index are parameters for powder characterization and flow property ${ }^{16,25,26}$ which depends on the size, shape, distribution of particles etc. ${ }^{25}$ The mean value of Bulk density, Tapped density, Hausner's ratio and Carr's index of KTN and KTK showed no significant difference. Tapped density was slightly higher in KTN indicating larger particle size and shape. Kushta (s) are nano particles, hence may not be perceived by these tests. Techniques, like XRD, FESEM/EDS, ICP-MS, etc. can give a better understanding.

XRD finding in samples KTN reveals presence of Copper $(\mathrm{Cu})$, Calcium Sulphate $\left(\mathrm{CaSO}_{4}\right)$ and Bassanite $\left(\mathrm{CaSO}_{4} ! 0.5 \mathrm{H}_{2} \mathrm{O}\right)$ phase where as in KTK, Copper Oxide (CUO), Anhydrite Calcium Sulphate $\left(\mathrm{Ca}\left(\mathrm{SO}_{4}\right)\right.$ and Potassium hydroxide $\left(\mathrm{KO}_{2}\right)$ (Table 1$)$. Conversion of Copper sulphate to Copper sulphate hydrate and oxide form was noted in TB [Table 1]. In Sample 2- TB, the reduction is involved in term of water of crystallization when compared to sample $1-\mathrm{TP}, \mathrm{Cu}$ was separated and form some metastable compound when compared to sample 1, Sharp peaks in the sample 1 graph suggests more crystallinity or less amorphous when compared with sample 2. Particle size reduction in this group may be due to new phase formation due to roasting in TB [Figure 2].

In KTN, XRD findings revealed Copper sulphate present initially, after processing with Margosa leaves / calcinations process is converted in Copper and Calcium Sulphate phase, where as in KTN Copper sulphate was converted into CUO Copper Oxide, and Calcium Sulphate $\left(\mathrm{CaSO}_{4}\right)$ phase Copper in KTK is converted in oxide form reveling more heat exposure. (Figures 3-4) [Table 1]

In XRD and FESEM/ EDS studies, peaks for calcium sulphate may be due to transfer of calcium from either the earthen pot or Azadirachta indica (Neem) leaves. Potassium hydroxide phase in sample KTK may be due to Margosa leaves which may have been undetected in KTN due to use of less quantity of leaves.Topographic data was set in with FESEM [Figure 5 - 7] Type of element with percentage was detected with EDS. [Figure 5,6] suggested that Copper sulphate and KT in sample 1 to 4 belonged to the complex group of minerals/elements containing in different proportions. ${ }^{27}$ In KTK and KTN both, Copper, Calcium, Sulphur, Chlorine, Magnesium, Silicon and Potassium were detected in EDS confirming the findings obtained from XRD. In sample 4 (KTK) increase in grain size of Calcium Sulphate crystallite are likely due to an increase in the quantum of heat and heating time. As per IC-MS findings, a heavy metal trace element in KTK and KTN were under the permissible limit as per WHO guidelines, except lead which was slightly beyond limit in KTK and KTN. ICP-MS studies revealed a slight reduction in all heavy metal trace elements in KTK. ${ }^{11}$ Thesource of raised $\mathrm{Pb}$ in ppm level may be extrinsic either may be from the earthen pot or contaminated Margosa leaves due to collection from urban pollution or Copper sulphate may itself be a source. ${ }^{28}$ Therefore, it is advisable to make sure that all the materials, water, pots etc. should be ascertained to be free from heavy metal contamination. The difference in particle size of KTK and KTN as estimated by XRD and FESEM / EDS was noted. Particle size was reduced in KTK, and can be a standard for the final perfect Kushta and may be one of the parameters that KTN is not fully formed. A gradual reduction in decreasing order from sample 1 to 4 was noted in XRD and SEM findings suggesting the effect of heat exposure and processing on the particle of $\mathrm{CUSO}_{4}$ and its formed phases.

XRD finding concludes that Copper Sulphate when compared in Sample 1, 3 and 4, is first converted in elemental CU in sample 3 then in Copper oxide in sample 4 due to increase in incineration time and heat. [Figure 1-4] Majority of peak observed is of calcium sulphate in Sample 4 (KTK) and also in sample 3 (KTN). It can also be learned that adding herbs with minerals while making Kushta seems appropriate as per classical Unani text / physicians and XRD, ICP-MS, FESEM, EDS, etc. Sophisticated analytical tests are strongly recommended for standardization of Kushta. ${ }^{18,19}$

Last few decades have shown rapid progress in nano medicine. Reduction of size has provided new potentials for the use of metallic elements and their compounds. Interest in Copper and its biocidal properties of its compounds have been known since ancient times. Recently, Copper nano particles and Copper oxide nano particles are known to be nonspecifically cytotoxic. The test drug also gave end - product as CUO in a nano form, and CU nano form can be used in infection..$^{29}$ Metal nano particles are now a new class of antimicrobials. ${ }^{30}$ Copper compounds show a range of biological actions, such as anti-inflammatory, antiproliferative, biocidal, antimicrobial, antitumor properties etc. ${ }^{31} \mathrm{CuO}$ nano particles also have significant antimicrobial action against a wide range of pathogens ${ }^{32,33}$ generated its applications to the biomedical field, such as wound dressings, treatment of infections etc. ${ }^{34}$ Ancient Unani physicians used this Kushta, end product of which is a CUO nano particle since ages for the same indication researched in recent time. In the present work, sulphate was converted first in elemental Copper then in Copper oxide in KTK, beside particle size reduction in $\mathrm{Cu}$ obtained in nano particulate justifies the use of KTK in wound and skin diseases. ${ }^{31}$ [Figure 5].

As per few reports, CUO may be toxic to mammalian cells, ${ }^{34}$ but, it is also considered as safe for humans if used externally and in low amounts. ${ }^{35}$ For oral use preliminary toxicity data for this particular Kushta was generated in this work. Acute toxicity was carried out displayed no toxicity signs and mortality in either group up to $2000 \mathrm{mg} / \mathrm{kg}$. This may be because both samples were converted into non-toxic end-product. The dose $2000 \mathrm{mg} / \mathrm{kg}$ is much higher than the therapeutic dose $(62.5 \mathrm{mg} / \mathrm{kg})$. Safety of the test drug cannot be guaranteed because most heavy metal have a cumulative effect, therefore, long term and special toxicity studies are needed to establish the complete safety profile. Safety of Kushta upto $2000 \mathrm{mg} / \mathrm{kg}$ in our study contradicts with $\mathrm{LD}_{50}$ of Copper sulphate alone which is $30 \mathrm{mg} / \mathrm{kg}$ in rats. In our study, $\mathrm{CuSo}_{4}$ was converted into Copper oxide and Calcium sulphate, which are relatively safer than $\mathrm{CuSo}_{4}$. Calcium sulfate, a calcium salt, is an inactive ingredient. ${ }^{36}$ This study proves the claim of Unani medicines that toxicity of the drug is reduced in Kushta form. The study proved prescience of ancient scholars who were using harmful drugs harmlessly by converting them into suitable dosage forms.

\section{CONCLUSION}

Study validated the perfect procedure of making, establishing characterization of Kushta Tutia, data for organoleptic characters, physicochemical parameters and sophisticated instrumental analysis 
developed can serve as standard for authentication of other Kushta(s) also. Differences in the analytical findings of KTN and KTK prove that imperfect method adopted for preparing Kushta can lead to change in final product and can alter the claimed therapeutic uses Kushta (s) as well as cause toxicity.

\section{ACKNOWLEDGEMENT}

The authors are thankful to, Department of Materials Engineering (In-charge CCD facility) and Mr AN Krishnamurty, Technician XRD, Indian Institute of Science, Bengaluru for providing XRD and FESEM / EDS facilities and Natural Remedies, Bengaluru for ICP-MS facility, Director National Institute of Unani Medicine for providing all the assistance in the work

\section{CONFLICT OF INTEREST}

The authors declare no Conflict of interests.

\section{Funding Source}

This is a post-graduation dissertation project and all the financial support was provided by National Institute of Unani Medicine, Bangalore an autonomous organization under Ministry of AYUSH Govt. of India

\section{Ethical Statement}

To demonstrate the Acute toxicity study of compounds, the minimum possible of animals was used. Acute Toxicity Study was carried out according to OECD Guidelines (423) after approval of IAEC of NIUM vide Reg. No. 971/b c/06/CPCSEA.

\section{ABBREVIATIONS}

nm: nanometer; gm: gram; ppm: Part per million: KTK: Kushta Tutia kamil (Perfect calx of Copper sulphate); KTN: Kushta Tutia Naqis (Imperfect calx of Copper sulphate); TP: Tutia powder (Copper sulphate powder); TB: Tutia Biryan (Roasted Copper sulphate); ICP-MS: Inductively Coupled Plasma- Mass Spectrometry; FESEM: Field emission scanning electron microscopy; EDS: Energy dispersive spectroscopy; XRD: X-ray Diffraction; FRLHT: Foundation for Revitalisation of Local Health Traditions; CUO: Copper Oxide; OECD: Organisation for Economic Co-operation and Development; NIUM: National Institute of Unani medicine; CPCSEA: Committee for the Purpose of Control and Supervision of Experiments on Animals; ANOVA: One-way analysis of variance; kg: Kilo gram; b.w.: Body weight; Cu: Copper; Ar: Arsenic; Cd: Cadmium; Hg: Mercury; Pb: Lead.

\section{REFERENCES}

1. Nadkarni AK. Indian material medica. $7^{\text {th }}$ Ed.Vol 2. Mumbai: Popular prakashan. 2010;52.

2. IImul KM. Advia Nafeesi. Vol. 265. New Delhi: Aijaz Publishing House [reprint]; 2007:348-349.

3. Ghani N. Khazain -al- Advia. Idarah Kitab Shifa New Delh (Reprint). 2010;63:1327-31.

4. Khan A. Muhit-I-Azam. 1sted. Urdu translation, Central council for research in Unani medicine (CCRUM). New Delhi (Reprint). 2013;94.

5. Kabeeruddin M. Makhzan -ul-Mufradat. IdaraKitab-U.S.-Shifa New Delhi (Reprint). 2007;162:163.

6. KitabutTaklees KM, Maseehi I, CCRUM. New Delhi [reprint]. 1922;67:69.

7. Vohora SB, Athar M. Mineral drugs Used in Ayudveda and Una ni Medicine. New Delhi: Narosa Publishing House; 2008. p. 113

8. National formulary of Una ni Medicine. Part 1. New Delhi. CCRUM. 2006:66(74):329
9. Joshi N, Sharma K, Peter H, Dash MK. Standardization and quality control parameters for Mukta Bhasma (calcined pearl). Anc Sci Life. 2015 JulySeptember:35(1):42-51. doi: 10.4103/0257-7941.164542, PMID 26600667, PMCID PMC4623633

10. Mohaptra S, Jha C. Physicochemical characterization of Ayurvedic bhasma (Swarna makshika bhasma): an approach to standardization. Int J Ayurveda Res. 2010;1(2). doi: 10.4103/0974-7788.64409.

11. Ali MA, Hamiduddin ZM, Ikram M, Ranjan R. Pharmaceutico - analysis Study.

12. Sarkar PK, Chaudhary AK. Ayurvedic Bhasma: the most ancient application of Nanomedicine. JSIR. 2010;69:901-5.

13. Inductively coupled plasma- mass spectrometry (ICP-MS). Philips innovation services.

14. Ali MA, Hamiduddin ZM, Ikram M, et al. Preliminary physiochemical evaluation of Kushta-e-Zaharmohra. A unique formulation of Una ni Medicine. Anc Sci Life. 2018.

15. Protocol for testing of Ayurvedic, Siddha and Una ni medicines. Vol. 15. Ghaziabad: government of India, Department of AYUSH, Ministry of Health and Family Welfare, Pharmacopoeial Laboratory for Indianmedicine; 2008;49.

16. The Japanese pharmacopoeia. 15th ed. Ministry of Health, Labour and Welfare;2006. p. 68.

17. Petersen EW, Likovich EM, Russell KJ, Narayanamurti V. Growth of ZnO Nano wires catalyzed by size-dependent melting of Au nanoparticles. Nanotechnology. 2009;20(40):405-603

18. Scanning electron microscope. https: // en.wikipedia. org/wiki/Scanning electron_microscope, accessed date 11.04.2020.

19. Energy-dispersive X-ray spectroscopy. Ray spectroscopy/Accessed date 11.04.2020. Available from: https://en.wikipedia.org/wiki/Energy-dispersive_ X- [cited 25/10/2021].

20. OECD guideline for testing of chemical. Vol. 423; 2001. Environment/testno-423-acute-oral-toxicity-acute-toxic-class method_978926407100 1en. Available from: https://www.oecd-ilibrary.org [cited 25/10/2021]

21. Rani S. Standardisation of Kushta: Classical and modern approaches. Int $J$ Unani Integr.

22. Rasheed A, Marri A, Naik MM. Standardization of Bhasma-importance and prospects. JPharm Res. 2011;4(6):1931-3.

23. Jagtap $C Y$, Prajapati $P$, Patgiri $B$, Shukla VJ. Quality control parameters for Tamra (Copper) Bhasma. Anc Sci Life. 2012;31(4):164-70. doi: 10.4103/02577941.107348, PMID 23661863.

24. Calcium; May 28 2020. Available from: http://en.m.wikipedia.org/wiki/Ca, accessed date 2020 [cited 25/10/2021].

25. Kumar T, Chandrashekar KS, Tripathi DK, Nagori K, Pure S, Agrawal S, Ansari TJ Standardization of 'GokshuradiChurna' Anayurvedicpolyherbal formulation. J Chem.

26. WHO. Bulk density and Tapped density of powders, 2012 https://. Medicines

27. Dorofeev GA, Streletskii AN, Povstugar IV, Protasov AV, Elsukov EP. Determination ofnanoparticle sizes by X-ray diffraction. Colloid J. 2012;74(6):675-85. doi: 10.1134/S1061933X12060051

28. Akan JC, Inuwa LB, Chellube ZM, Lawan B. Heavy metals in leaf, stem bark of neem tree(Azadirachta indica) and roadside dust in Maiduguri Metropolis Borno State, Nigeria. Environ Pollut. 2013;2:1, 88.

29. Galhardi CM, Diniz YS, Rodrigues HG, Faine LA, Burneiko RC, Ribas BO, Novelli.

30. Hsueh YH, Tsai PH, Lin KS. PH-dependent antimicrobial properties of copper oxidenanoparticles in Staphylococcus aureus. Int J Mol Sci. 2017;18(4):793. doi: 10.3390/ijms18040793, PMID 28397766.

31. Szymanski P, Fraczek T, Markowicz M, Mikiciuk-Olasik E. Development of copper baseddrugs, radio pharmaceuticals and medical materials. Biometals. 2012;25(6):1089-112. doi: 10.1007/s10534-012-9578-y, PMID 22914969.

32. Horowitz AM. A report on the NIH Consensus Development Conference on Diagnosis andManagement of Dental Caries Throughout Life. J Dent Res. 2004:83:Spec No C:C15-7-. doi: 10.1177/154405910408301s03, PMID 15286115 .

33. Toodehzaeim $\mathrm{MH}$, Zandi $\mathrm{H}$, Meshkani $\mathrm{H}$, Hosseinzadeh Firouzabadi A. The effect of CuOnanoparticles on antimicrobial effects and shear bond strength of orthodontic adhesives. J Dent (Shiraz). 2018;19(1):1-5. PMID 29492409.

34. Grigore ME, Biscu ER, Holban AM, Gestal MC, Grumezescu AM. Methods of synthesis, properties and biomedical applications of $\mathrm{CuO}$ nanoparticles. Pharmaceuticals (Basel). 2016;9(4):75. doi: 10.3390/ph9040075, PMID 27916867.

35. Borkow G, Gabbay J. Biocidal textiles can help fight nosocomial infections. MedHypotheses. 2008;70(5):990-4. doi: 10.1016/j.mehy.2007.08.025, PMID 17959322.

36. Calcium sulphate; 2020 [cited may 28]. Available from: https://www.drugs.com/ inactive/calcium-sulfate-14.html.

Article History: Submission Date : 16-08-2021; Revised Date : 30-09-2021; Acceptance Date : 24-10-2021.

Cite this article: Mehfooz S, Wadud A, Hamiduddin, Ranjan R. Scientific Appraisal of Classical Calcination Process of Kushta (calx) in Reference to Calx of Copper Sulphate. Int. J. Pharm. Investigation. 2021;11(4):368-73. 